\title{
CONTRATAÇÕES PÚBLICAS DO IFCE - CAMPUS IGUATU: ANÁLISE SOB A ÓPTICA DA SUSTENTABILIDADE
}

IFCE-CAMPUS IGUATU'S PUBLIC PROCUREMENTS: ANALYSIS FROM THE PERSPECTIVE OF SUSTAINABILITY

\author{
Anna Ariane Araújo de Lavor (1) \\ Doutoranda na Universidade Vale \\ do Taquari (UNIVATES) - Lajeado \\ (RS), Brasil.
}

\section{Luciana Turatti}

Professora do Programa de Pós-Graduação em Sistemas Ambientais Sustentáveis (PPGSAS) e do Programa de Pós-Graduação em Ambiente e Desenvolvimento (PPGAD) na UNIVATES - Lajeado (RS), Brasil.

\section{Endereço para correspondência:}

Anna Ariane Araújo de Lavor Rua Carlos Colares, 8- Esplanada CEP 63505-180 - Iguatu (CE), Brasil E-mail: annaariane@hotmail.com

Recebido em: 17/09/2018

Aceito em: 21/04/2019

\section{RESUMO}

Este artigo tem como escopo o estudo do processo de difusão das compras públicas sustentáveis no Brasil e, de forma mais específica, em uma instituição de caráter federal, tendo em vista que, na última década, a evolução normativa envolvendo tal tema tem considerado a possibilidade de estas não considerarem somente os aspectos econômicos quando da sua realização. A instituição escolhida foi o Instituto Federal de Educação, Ciência e Tecnologia do Ceará - Campus Iguatu. Foram analisados todos os seus processos de aquisição no exercício de 2015. O intuito da pesquisa foi analisar se a instituição adotou critérios de sustentabilidade, quando das compras públicas, quais critérios foram adotados e como ocorreu essa inserção. A pesquisa teve caráter descritivo e exploratório, e a abordagem foi qualitativa. Ao final, ficou demonstrado que o Instituto Federal de Educação, Ciência e Tecnologia do Ceará - Campus Iguatu, no ano analisado, possuiu percentuais acima da média nacional, quanto à adoção de critérios de sustentabilidade.

Palavras-chave: sustentabilidade; contratações públicas; desenvolvimento.

\section{ABSTRACT}

This article has as its scope the study of the sustainable public purchases' process of diffusion in Brazil;more specifically, in a federal institution, considering that in the last decade the normative evolution involving such subject has considered the possibility of these, not to consider only the economic aspects when they are carried out. The institution chosen was the Federal Institute of Education, Science and Technology of Ceará Campus Iguatu. All its acquisition processes were analyzed in the year of 2015. The purpose of the research was to analyze whether the institution adopted criteria of sustainability, when the public purchases occurred, which criteria were adopted and how this insertion occurred. The research was descriptive and exploratory, with a qualitative approach. In the end, it was demonstrated that the Federal Institute of Education, Science and Technology of Ceará - Campus Iguatu had percentages above the national average regarding the adoption of sustainability criteria in the analyzed year.

Keywords: sustainability; public contracts; development. 


\section{INTRODUÇÃO}

As contratações governamentais são regulamentadas pela Lei no 8.666/93 (BRASIL, 1993), que estabelece normas gerais sobre licitações e contratos administrativos pertinentes a obras, serviços e aquisição de bens. O artigo 3ㅇ do dispositivo legal citado prevê, de forma expressa, que a negociação realizada deve garantir a promoção do desenvolvimento nacional sustentável, assim como devem ser respeitados os princípios básicos da legalidade, da impessoalidade, da moralidade, da igualdade, da publicidade, da probidade administrativa, da vinculação ao instrumento convocatório, do julgamento objetivo e dos que lhes são correlatos.

Para corroborar com o propósito previsto na lei de licitações, no sentido de assegurar o desenvolvimento nacional sustentável, em 2012 foi aprovado o Decreto no 7.746, que propôs a regulamentação das denominadas licitações sustentáveis, estabelecendo critérios, práticas e diretrizes para as contratações realizadas pela Administração Pública Federal (BRASIL, 2012). Assim, o presente artigo visou, por meio dos debates nele travados e dos resultados apresentados, disseminar a prática das contratações sustentáveis, bem como estimular os gestores e os planejadores das compras públicas para que estes tomem decisões direcionadas às ações sociais, econômicas e ambientais em prol do desenvolvimento sustentável. Para isso, apresenta os resultados de uma investigação empírica realizada no Instituto Federal de Educação, Ciência e Tecnologia do Ceará (IFCE) - Campus Iguatu, onde foram analisados todos os procedimentos licitatórios do exercício de 2015, sob a óptica da sustentabilidade.
A instituição fica localizada na cidade de Iguatu, região centro-sul do Ceará. A entidade foi escolhida para a pesquisa pelo expressivo quantitativo orçamentário de $\mathrm{R} \$$ 6.405.666,06 no exercício de 2015 (período utilizado na pesquisa), bem como pelo total de servidores (205 servidores: 115 técnicos administrativos, 77 professores efetivos, 10 professores substitutos e três temporários) e alunos (total de 973: 120 internos, 50 semi-internos e 803 externos) que precisam ser atendidos pelas contratações públicas realizadas. $O$ trabalho realizado na instituição pesquisada se propôs a analisar em que medida esta adotou critérios de sustentabilidade quando das compras públicas realizadas ao longo do ano de 2015, quais critérios foram adotados e como ocorreu essa inserção.

Para dar consecução aos objetivos propostos, a pesquisa assumiu o caráter descritivo e exploratório. Quanto ao procedimento técnico, utilizou-se a abordagem qualitativa como forma de análise dos procedimentos de compras identificados no ano de análise. Os parâmetros e os critérios para a análise das contratações públicas foram retirados da legislação vigente, especialmente do Decreto $\mathrm{n}-7.746 / 2012$, que trata da sustentabilidade nas compras governamentais, bem como das dimensões de sustentabilidade (dimensões jurídico-política, ética, social, econômica, ambiental, cultural, distribuição territorial equilibrada, sustentabilidade do sistema internacional e liberdade de escolhas e oportunidades) adotadas por Sachs, Freitas e Veiga, que orientaram a construção do referencial teórico.

\section{REFERENCIAL TEÓRICO}

\section{Sustentabilidade: um conceito multidisciplinar}

A sustentabilidade pode ser entendida como a disponibilidade dos recursos existentes para toda a população e seus descendentes, ou seja, o desenvolvimento sustentável atende às necessidades socioeconômicas de uma população, sem, contudo, comprometer o atendimento das demandas das gerações futuras (ONU, 1987). O desenvolvimento sustentável não se limita somente à questão ambiental, pois a ideia de sustentabilidade também se refere a outros segmentos da sociedade, como economia, educação, cultura e qualidade de vida. Ou seja, o conceito utilizado no presente artigo defende que existem várias dimensões que se completam para definir o desenvolvimento sustentável. Para isso, no decorrer deste trabalho, far-se-á uma análise das dimensões apresentadas por Veiga, Freitas e Sachs, cotejando-as com as contratações públicas e em sintonia com a legislação em vigor no âmbito das contratações públicas. Os autores José Eli da Veiga, Juarez Freitas e Ignacy Sachs foram escolhidos para fundamentar a pesquisa, por se colocarem como alguns dos principais autores a adotar uma abordagem multidimensional quando da significação do termo sustentabilidade. 
Veiga (2006) destaca que não é possível auferir o desenvolvimento apenas a partir de índices, como o Índice de Desenvolvimento Humano (IDH). Estes são apenas um ponto de partida, pois o desenvolvimento é amplo e complexo e não poderia ser captado apenas por números, pois estes não seriam capazes de capturar ou representar fatores essenciais da vida das pessoas, tais como a capacidade de participar das decisões que lhe afetam. Em outra obra, o autor afirma que o desenvolvimento, dessa forma, seria a expansão das liberdades substantivas, ou seja, a liberdade real de empoderamento para suprir suas mais diversas necessidades e escolhas (VEIGA, 2008). Para ele, o desenvolvimento demanda a remoção das fontes de privações de liberdade preponderantes, tais como: "Pobreza e tirania, carência de oportunidades econômicas e destituição social sistemática, negligência dos serviços públicos e intolerância ou interferência dos Estados repressivos" (VEIGA, 2008, p. 34).

Veiga justifica essa visão ao afirmar:

\begin{abstract}
O processo de desenvolvimento pode expandir as capacidades humanas, expandindo as escolhas que as pessoas têm para viver vidas plenas e criativas. E as pessoas são tanto beneficiárias desse desenvolvimento, como agentes do progresso e da mudança que provocam. Este processo deve beneficiar todos os indivíduos equitativamente e basear-se na participação de cada um deles (VEIGA, 2005, p. 249).
\end{abstract}

Assim, as políticas públicas devem estabelecer prioridades a fim de preservar e expandir as liberdades substantivas desfrutadas hoje, sem, contudo, comprometer a capacidade das futuras gerações usufruírem de liberdades semelhantes ou maiores. É a administração pública que deve assegurar que isso ocorra efetivamente, para que todos possam ter a garantia constitucional de equidade.

Um autor que apresenta as dimensões da sustentabilidade de forma bastante didática é Juarez Freitas. $\mathrm{O}$ autor entende que a sustentabilidade possui diversas dimensões: social, ética, jurídico-política, econômica e ambiental. Para Freitas (2012), o desenvolvimento segundo a dimensão social não pode ser excludente, injusto e discriminatório. Em tal dimensão estariam englobados os direitos fundamentais sociais, por exemplo, o direito a um ambiente de trabalho decente, salubre e livre de contaminações físicas ou psicológicas.
Ao tratar da dimensão ética, Freitas (2012) inicialmente apresenta um conceito para o termo ética informando que esta equivale a um conjunto de normas e valores dentro de uma sociedade. Como tal, é indispensável na construção do desenvolvimento justo. Assim, a sustentabilidade, na visão do autor, também impõe uma ética universal concretizável, a qual seria vital para defender a ideia de realocar os recursos públicos à universalização do desenvolvimento com bem-estar.

Já a dimensão jurídico-política, segundo Freitas (2012), apresenta-se no poder-dever do Estado de proteger a liberdade e o direito ao futuro de cada cidadão, o que encontra guarida na previsão constitucional dos direitos e dos deveres fundamentais. Para atingir tal finalidade, esse segmento do desenvolvimento sustentável garantiria o "direito à boa Administração Pública, com a indeclinável regulação das atividades essenciais e socialmente relevantes" (FREITAS, 2012, p. 70), e isso deve acontecer em todos os atos administrativos, inclusive nas contratações públicas.

Quando da apresentação da dimensão econômica, Freitas (2012) lembra que a economia engloba a produção e o consumo de bens/serviços, bem como a forma que eles serão distribuídos entre as pessoas, o que, contudo, pode ocorrer de forma excludente, desregulando o desenvolvimento. Dessa forma, defende que o aspecto econômico não pode ser separado da medição das consequências de longo prazo, ou seja, o consumo e a produção precisam passar por uma reestruturação visando à sustentabilidade.

Tratando da dimensão ambiental, o autor lembra que quando se fala em sustentabilidade não há como deixar de fora a responsabilidade humana sobre o meio ambiente, pois o comprometimento da biodiversidade causa severo empobrecimento da qualidade de vida, ou seja, "não pode haver qualidade de vida e longevidade em um ambiente degradado" (FREITAS, 2012, p. 65). Assim, é vedado ao governo se eximir de cuidar do meio ambiente em todos os seus atos administrativos, inclusive por meio das contratações públicas.

Outro autor que aborda diferentes dimensões dentro do contexto do desenvolvimento sustentável é Ignacy Sachs (2004). Para ele, embora o desenvolvimento não possa ocorrer sem crescimento, este tem valor apenas instrumental, sendo somente um dos aspectos indispensáveis. Sachs (2002) acrescenta a cultura, a distri- 
buição territorial equilibrada e a sustentabilidade do sistema internacional como elementos necessários ao desenvolvimento sustentável. A cultura é um fenômeno social que corresponde a um componente indispensável na vida de cada indivíduo. Por isso, Sachs (2002) ressalta que a cultura tem papel de destaque no desenvolvimento humano, e, consequentemente, no desenvolvimento sustentável. Como exemplos da dimensão cultural do desenvolvimento, podemos citar o turismo sustentável, as indústrias culturais e criativas, a revitalização urbana baseada em seu patrimônio, entre outros.

Já a distribuição territorial equilibrada deve ser analisada por seu sentido econômico e social, a fim de evitar a crescente dinâmica de exclusão socioespacial, bem como obter uma divisão rural-urbana mais equilibrada e melhor distribuição das atividades econômicas. Portanto, é um elemento essencial para o desenvolvimento harmonioso e sustentável. A dimensão da sustentabilidade do sistema internacional, segundo Sachs (2002), é baseada na garantia da paz e na promoção da cooperação internacional. Esses fatores englobam diversos elementos, tais como gestão do meio ambiente e dos recursos naturais, prevenção das mudanças climáticas globais, proteção da diversidade biológica e cultural, gestão do patrimônio mundial, entre outros.
Dentro das contratações públicas é possível adotar uma visão multidisciplinar da sustentabilidade, e isso ocorre em sintonia com o Decreto no 7.746 de 2012, que regulamenta e estabelece critérios, práticas e diretrizes para a promoção do desenvolvimento sustentável no âmbito das contratações realizadas pela Administração Pública Federal. O referido decreto não apresenta uma definição de sustentabilidade, abrindo espaço, dessa forma, para o emprego do conceito moldado pela visão multidisciplinar, que, por sinal, é considerado mais amplo e moderno, opção esta escolhida para o presente trabalho, em detrimento do tripé da sustentabilidade (Triple BottomLine).

Ante o exposto, observa-se que todas as dimensões (jurídico-política, ética, social, econômica, ambiental, cultural, distribuição territorial equilibrada, sustentabilidade do sistema internacional e liberdade de escolhas e oportunidades) do desenvolvimento sustentável defendidos por Veiga, Freitas e Sachs podem e devem ser inseridas nas características desejáveis e nas estruturas de abordagem das contratações públicas. Assim, as dimensões da sustentabilidade citadas serviram de guia para orientar a análise dos critérios ora existentes ou a serem propostos no que tange à realidade do IFCE Campus Iguatu, Ceará.

\section{CONTRATAÇÕES PÚBLICAS SUSTENTÁVEIS}

Silva et al. (2018) defendem que a contratação pública sustentável é entendida como o processo pelo qual organizações, a fim de satisfazer suas necessidades de bens, serviços e obras de construção, avaliam os custos reais de suas aquisições, buscando gerar benefícios não apenas para a administração pública, mas também para a sociedade e a economia, minimizando os danos ao meio ambiente. As contratações públicas sustentáveis estão recebendo uma crescente atenção como consequência de um aumento nos desafios para o desenvolvimento dos países. De acordo com Ross (2012), as contratações públicas representam aproximadamente $15 \%$ do produto interno bruto (PIB) nos países da Organização para a Cooperação e Desenvolvimento Econômico (OCDE) e até $25-30 \%$ do PIB nos países em desenvolvimento, e os governos usam progressivamente esse poder de compra para influenciar os mercados para a inovação e a sustentabilidade. No Brasil, representam de 15 a 20\% do PIB nacional (CADER DA SILVA; BARKI, 2012).
A Constituição Federal dispõe, em seu art. 37, XXI, que exceto em casos taxativamente previstos em lei, as compras públicas devem ser realizadas por meio de licitação (BRASIL, 1988). As contratações públicas são regulamentadas pela Lei $n$ - 8.666/93, a qual impõe que deve ser garantida a promoção do desenvolvimento nacional sustentável, assim como devem ser respeitados os princípios básicos da legalidade, da impessoalidade, da moralidade, da igualdade, da publicidade, da probidade administrativa, da vinculação ao instrumento convocatório, do julgamento objetivo e dos que Ihes são correlatos. Meirelles, Azevedo e Aleixo Filho (2011) explicam que esse procedimento realizado pela administração pública deve selecionar a proposta mais vantajosa para cada serviço/compra, porém tal escolha, além de satisfazer a demanda, deve contribuir para o desenvolvimento sustentável e a consolidação de cadeias produtivas de bens e serviços.

Teixeira (2013) destaca que as contratações públicas não precisam visar apenas ao menor preço para suprir suas 
necessidades imediatas: "Percebe-se, portanto, a possibilidade de utilização das contratações públicas para a obtenção de resultados paralelos que vão além do simples objetivo de suprimento do Estado e além do paradigma da eficiência estrita que se traduz em comprar mais, mais rápido e por um menor preço" (TEIXEIRA, 2013, p. 28).

Contudo, as contratações públicas não podem ser totalmente previstas em um pequeno rol taxativo. Segundo orientações previstas especialmente no Decreto no 7.746/2012, para que os órgãos governamentais possam realizar contratações sustentáveis, é necessária a adoção de diversas medidas, tais como (BRASIL, 2012):

- a identificação dos bens, serviços e obras necessários pela instituição para analisar a viabilidade de adotar exigências de sustentabilidade nas licitações futuras, optando por produtos equivalentes que causem menor impacto ambiental;

- capacitação dos servidores responsáveis pelas contratações, bem como toda a equipe de apoio;

- análise do mercado, por meio da identificação e da avaliação de recursos materiais e humanos disponíveis, especialmente no mercado local, a fim de fomentar o crescimento da economia regional;

- utilização de tratamento favorecido, diferenciado e simplificado para as microempresas (ME) e as empresas de pequeno porte (EPP), os agricultores familiares, os produtores rurais, as pessoas físicas, os microempreendedores individuais (MEI) e as sociedades cooperativas de consumo, nos termos do Decreto no 8.538/2015;

- verificação do grau de sustentabilidade dos produtos ou da condição de geração de menor impacto ambiental em relação aos seus similares, na certificação do Instituto Nacional de Metrologia, Normalização e Qualidade Industrial (INMETRO). Quando possível, que os bens sejam constituídos, no todo ou em parte, de material reciclado, atóxico, biodegradável, conforme normas brasileiras aprovadas pela Associação Brasileira de Normas Técnicas (ABNT) 15448-1 e 15448-2;

- exigência de observância da legislação trabalhista pelas empresas contratadas;

- observância do ciclo de vida dos produtos.
Além disso, conforme o artigo 2 e e seguintes do Decreto no $7.746 / 2012$, a administração pública, ao adquirir bens e contratar serviços e obras, deve seguir de forma objetiva, delimitada e justificada os critérios de sustentabilidade definidos no instrumento convocatório. Tais regras devem ser dispostas no edital e contrato como uma especificação técnica do objeto ou como obrigação da contratada (BRASIL, 2012). Como se verifica, a norma concede uma abertura para que os órgãos públicos adotem critérios de sustentabilidade, não mais se limitando à busca pelo menor preço.

Segundo Garcia e Ribeiro (2012), existem quatro possíveis momentos viáveis para a delimitação da sustentabilidade nas contratações públicas: definição do objeto; fase de habilitação; julgamento das propostas; e obrigações do contratado. O primeiro momento em que será possível a inserção de critérios de sustentabilidade na contratação pública é em sua fase preparatória, mais precisamente na delimitação do objeto pretendido, contudo isso deverá ocorrer de forma técnica e fundamentada (GARCIA; RIBEIRO, 2012). Por exemplo, solicitando que o bem adquirido tenha certificação da qualidade do produto ou do processo de fabricação, sobre o aspecto ambiental. Outro momento possível para a adoção dos critérios de sustentabilidade ocorre quando do julgamento da proposta. Garcia e Ribeiro (2012) afirmam que é possível conferir preferência às propostas que produzam maiores benefícios ambientais, o que estimulará a busca pela excelência em sustentabilidade, desde que os critérios adotados sejam elencados de forma clara e objetiva, a fim de garantir a ampla concorrência e afastar o risco de privilégios ilícitos em favor de licitantes. Por último, pode-se admitir que no contrato esteja prevista a obrigação de que a empresa licitada atenda a exigências de sustentabilidade na execução do objeto contratado. Isso pode ser feito, por exemplo, ao se estipular uma cláusula que requisite à empresa contratada orientar e capacitar seus prestadores de serviços, fornecendo informações necessárias para sua perfeita execução, incluindo noções de responsabilidade socioambiental, ou ainda ao requerer a promoção da remoção de todo o entulho gerado na obra pública, dando a ela destinação adequada.

Cabe salientar que o artigo 2ํㅡ, parágrafo único, do Decreto no $7.746 / 2012$, demonstrou a preocupação do legislador com a manutenção da competividade do certame e com a prevenção de possíveis fraudes, ao determinar que a adoção de critérios e práticas de sustentabilidade 
deverá ser objetivamente justificada nos autos (BRASIL, 2012). De acordo com Lavor e Turatti (2018), para que uma contratação pública seja sustentável é necessário que as instituições não analisem apenas o menor preço proposto, e sim que proposta seria capaz de produzir menores impactos ambientais ao mesmo tempo em que gera benefícios econômicos e sociais, porém sem perder a objetividade, a motivação, a eficácia, a eficiência, bem como os princípios da licitação.

Contudo, Biage e Calado (2015) destacam que a efetivação das contratações públicas sustentáveis é recente e poucas são as pesquisas científicas sobre esse assunto, de forma que ainda é limitado o conhecimento científico sobre o processo de implementação, as dificuldades e as barreiras existentes. Gelderman, Semeijn e Vluggen (2017) também relatam que apenas um pequeno número de estudos investigou o papel do setor público no desenvolvimento de iniciativas de sustentabilidade. Dessa forma, analisar os procedimentos e os critérios utilizados nas contratações de uma instituição pública federal irá contribuir para ampliar o debate sobre esse contemporâneo tema.

\section{PRINCIPAIS CRITÉRIOS DE SUSTENTABILIDADE UTILIZADOS NA ANÁLISE DOS DADOS}

Todas as dimensões da sustentabilidade defendidas especialmente por Sachs, Freitas e Veiga podem ser utilizadas quando se analisa a sustentabilidade conforme as contratações públicas: dimensões jurídico-política, ética, social, econômica, ambiental, cultural, distribuição territorial equilibrada, sustentabilidade do sistema internacional e liberdade de escolhas e oportunidades. Tais dimensões serão explicadas no decorrer do referen- cial teórico. Ocorre que, para a análise do objeto proposto neste artigo, não será utilizada a dimensão da sustentabilidade do sistema internacional, pois o IFCE - Campus Iguatu não realizou licitações internacionais durante o período de coleta dos dados para o presente trabalho. As demais dimensões serão utilizadas para avaliar os critérios de sustentabilidade das contratações da instituição, com destaque para os seguintes itens.

\section{Dimensão social, econômica, de liberdade de escolhas e oportunidades}

A seguir, são apresentados critérios licitatórios que potencialmente alcançam de forma simultânea as dimen- sões: social, econômica e de liberdade de escolhas e oportunidades.

\section{Benefícios para as microempresas e as empresas de pequeno porte}

Uma forma eficaz de atender às dimensões social, econômica e de liberdade de escolhas e oportunidades é por meio da aplicação de benefícios para as $\mathrm{ME}$ e as EPP. O Brasil possui 10,3 milhões de ME e EPP, representado $52 \%$ dos empregos com carteira assinada e $40 \%$ dos salários pagos (BRASIL, 2015b). Tais empresas historicamente demonstram dificuldades para se manter no mercado e concorrer com as grandes empresas. Uma das formas de se aumentar a competitividade dessas empresas, bem como criar emprego e renda para uma parcela significativa da população, é garantir melhores condições para que as micro e pequenas empresas participem das contratações públicas. Para isso, existem várias ferramentas previstas na Lei Complementar no 123/2006 (BRASIL, 2006) e no Decreto $n$ o $8.538 / 2015$, que possibilitam maiores oportunidades para que as ME e as EPP participem de maior quantidade de compras governamentais:

- Licitação com participação exclusiva de ME/EPP: esse benefício está previsto no artigo 60 do Decreto $8.538 / 2015$ e pode ser utilizado nas contratações de valores até $\mathrm{R} \$ 80 \mathrm{mil}$ por item/grupo licitado (BRASIL, 2015b);

- Margem de preferência para ME/EPP: a margem de preferência, prevista no art. 44 da Lei Complementar no 123/2006 (BRASIL, 2006) e no Decreto no 8.538/2015 (BRASIL, 2015a), ocorre quando uma micro ou pequena empresa oferece uma proposta até $10 \%$ superior ao preço válido ofertado no certame. Nessa situação, ocorre o chamado empate ficto e, com isso, a micro e pequena em- 
presa é chamada para manifestar se tem interesse em fazer uma oferta inferior àquela considerada vencedora da licitação;

- Prazo diferenciado para a comprovação da regularidade fiscal e trabalhista das ME/EPP: para as ME e as EPP, somente é exigida a comprovação no momento da assinatura do contrato, ou seja, não precisa comprovar esse requisito para participar do certame;

- Exigência de subcontratação de ME/EPP: nos instrumentos convocatórios, os órgãos podem exigir a subcontratação de ME e EPP. Contudo, deve haver um percentual mínimo a ser subcontratado e o percentual máximo admitido, sendo vedada a sub-rogação completa ou da parcela principal da contratação (BRASIL, 2015a);

- Cota para participação exclusiva de ME/EPP: se não houver prejuízo para o objeto licitado, os órgãos da administração pública devem, nas licitações para a aquisição de bens de natureza divisível, reservar cota de até $25 \%$ do objeto para a contratação de ME e EPP (BRASIL, 2015a).

- Prioridade para produtos nacionais: o artigo 9으, § II, g, prevê a possibilidade de priorizar a aquisição de produtos de origem nacional exclusivamente nos casos de propostas que se enquadrarem nas margens de preferência. Esse requisito tem grande importância, pois ajuda a fortalecer a indústria nacional e toda a cadeia produtiva envolvida;

- Tratamento diferenciado para agricultores, MEI, produtores rurais pessoa física e sociedades cooperativas de consumo: a legislação brasileira (Lei Complementar no 123/2006, Decreto no 8.538/2015, entre outros instrumentos normativos) admite tratamento diferenciado e simplificado para favorecer licitantes que não possuem grandes condições téc- nicas e financeiras, tais como as ME, as EPP, o agricultor familiar, o produtor rural pessoa física, o MEI e as sociedades cooperativas de consumo. Esse favorecimento legal justifica-se pelo fato de tais categorias possuírem menores recursos técnicos, financeiros, necessitando de impulso para dar igualdade de condições para concorrer com as grandes empresas nos processos licitatórios. Tal atitude pode contribuir para o desenvolvimento econômico social e regional. Com base no Decreto $n=8.538 / 2015$ (BRASIL, 2015a), as ME e as EPP locais também podem ter direito a uma nova margem de preferência em relação a outras sediadas fora da região, nos casos de licitação exclusiva, subcontratação e cota reservada. Além disso, com base no mesmo diploma legal, também pode ser estipulada margem de preferência de $10 \%$ para agricultores familiares e pequenos produtores rurais (pessoas físicas), da mesma forma que é concedido para as ME e as EPP no artigo 44, da Lei Complementar no 123/2006. $O$ decreto também prevê prazo diferenciado para a comprovação de regularidade fiscal, prevista no art. 42 da Lei Complementar no 123/2006 para agricultores familiares, produtores rurais pessoa física, MEl e sociedades cooperativas de consumo;

- Margem de preferência para empresas que cumprem o sistema de reserva de vagas para pessoas com deficiência: em 2015, a Lei no 8.666/93 foi alterada, acrescentado a possibilidade de se conceder, como critério de desempate, a margem de preferência para os fornecedores que comprovem cumprimento de reserva de cargos prevista em lei para pessoa com deficiência ou para reabilitado da Previdência Social, e que atendam às regras de acessibilidade previstas na legislação (BRASIL, 1993). Tal medida busca a inclusão social, a promoção da equidade, bem como o exercício de direitos das pessoas portadoras de deficiência.

\section{Aquisição de produtos da agricultura familiar para alimentação escolar}

A Lei no $11.947 / 2009$ determina que no mínimo $30 \%$ do valor repassado a estados, municípios e Distrito Federal para o Programa Nacional de Alimentação Escolar (PNAE) deve ser utilizado na compra de gêneros alimentícios oriundos da agricultura familiar (BRASIL, 2009). Tal medida tem como objetivo incentivar o desenvolvimento sustentável, pois estimula a aquisição de gêneros alimentícios diversificados, produzidos em âmbito local, dando preferência para a agricultura familiar e para empreendedores familiares rurais, respeitando a cultura e os hábitos alimentares saudáveis, contribuindo para o bem-estar dos alunos e para o fortalecimento das cadeias produtivas da região. Embora a legislação não preveja percentuais para as instituições de ensino federais, estas podem também adotar esse relevante critério de sustentabilidade. 
Uma forma de garantir a participação desses grupos nos processos de compras seria com a criação de um cadastro ou banco de dados local feito pela própria instituição, ou que poderia ser feito por meio do sistema de cadastramento de fornecedores (SICAF) do governo federal, a fim de catalogar e identificar possíveis fornecedores dessas categorias sediados na região, juntamente com suas linhas de fornecimento. Posteriormente, a instituição os notificaria sobre as licitações e buscaria facilitar a formação de parce- rias ou subcontratações, de que tratam o art. 20 do Decreto $n=8.538 / 2015$. Outra ação simples, mas que faria a diferença para maior participação dessas categorias nas contratações, seria publicar em jornais locais e divulgar em rádios comunitários da cidade os processos de compras vigentes na instituição, visto que esses grupos não costumam acompanhar o diário oficial e o site de compras do governo federal (Comprasnet).

\section{Verificação se as empresas concorrentes ferem princípios constitucionais}

A Lei $n$ - 8.666/93 exige que as empresas participantes dos certames apresentem declaração de que não emprega menores de 18 anos em trabalho noturno, perigoso ou insalubre, bem como não tem trabalhadores menores de 16 anos, salvo na condição de aprendiz, a partir de 14 anos. Também é previsto a consulta às Certidões Negativas perante o

\section{Dimensão ética e jurídico-política}

\section{Transparência e ações de fiscalização}

Gelderman, Semeijn e Vluggen (2017) defendem que transparência fornece a conexão ativa com as partes interessadas internas e externas para melhorar os processos, garantir a cooperação e incentivar uma base de fornecedores mais ampla para os contratos públicos, facilitando, consequentemente, a fiscali-

\section{Dimensão cultural}

A cultura é um fenômeno social que corresponde a um componente ativo na vida do ser humano e manifesta-se nos atos mais corriqueiros de sua conduta, portanto cada indivíduo é criador e propagador de cultura (MOREIRA; CANDAU, 2003). Reconhecendo essa função da cultura, a Rio+20 passou a incluir esse elemento nas discussões sobre desenvolvimento, conforme informações da Organização das Nações Unidas para a Educação, a Ciência e a Cultura (UNESCO, 2017), que cita como exemplos o turismo sustentável, as indústrias culturais e criativas, a revitalização urbana baseada em seu patrimônio, entre outros.

Assim, em uma contratação pública, por exemplo, para atender essa dimensão da sustentabilidade, o órgão contratante pode adotar diversos critérios, entre eles:
Instituto Nacional do Seguro Social (INSS), o Fundo de Garantia do Tempo de Serviço (FGTS) e a Justiça do Trabalho, que têm como finalidade ser instrumento concretizador de direitos fundamentais dos empregados das empresas fornecedoras, por ser um meio coercitivo indireto de execução das verbas trabalhistas.

zação dos atos administrativos. Para isso, todos os contratos (independentemente da modalidade da contratação) precisam ser publicados no Diário Oficial da União. Legalmente, também é exigido que as licitações com valores acima de $\mathrm{R} \$ \mathbf{6 5 0}$ mil sejam publicadas em jornais de grande circulação.

- Em serviços de engenharia, construir obras que mantenham harmonia com a arquitetura local, respeitando assim a regionalidade cultural e social;

- Em contratações para merenda escolar, poderiam ser licitados itens da cultura local, como rapadura, galinha caipira, produtos tipicamente locais (no caso em questão, produtos nordestinos). Essa ação, por respeitar a identidade da região, atenderia a dimensão cultural, bem como a social e de distribuição territorial, visto que, em geral, quem produz tais itens são pequenos produtores e agricultores familiares;

- Nos serviços de contratação voltados para a urbanização de praças, ruas e órgãos públicos, o órgão licitante poderia exigir que fossem plantadas árvores nativas, como forma de observar as dimensões ambiental e cultural. 


\section{Dimensão econômica}

A administração pública deve ser "preventiva, precavida e eficaz (não apenas eficiente)" (FREITAS, 2015, p. 120), e o governo pode regular o mercado, gerando uma economia sustentável utilizando as contratações públicas como uma ferramenta nesse sentido, por meio de diversas medidas, tais como: pesquisas de preço pré-licitatórias, cláusulas contratuais exigindo garantia de produtos e serviços, contratações compartilhadas, entre outras.

Uma ferramenta que começa a ser disseminada nas contratações públicas, que pode dar bons resultados para o desenvolvimento sustentável, são as contratações compartilhadas. Tais contratações são realizadas entre vários órgãos e permitem melhor planejamento das necessidades institucionais, bem como considerável redução de custos. Isso acontece, pois a venda de produtos em grande escala permite menores custos (para a administração pública e para empresa contratada), além da redução da burocracia

\section{Dimensão ambiental}

Diversas são as formas de atender à dimensão ambiental nos processos licitatórios, contudo, destacam-se: contratação de serviços de limpeza e conservação, nos termos do Decreto no 5.940/2006; destinação adequada dos entulhos gerados em contratação de serviços de engenharia; preferência e dos esforços necessários ao procedimento licitatório, que será realizado apenas por um órgão, sendo que os demais órgãos participantes vão apenas aderir ao procedimento.

Um exemplo desse modelo foi adotado por órgãos assessorados pela Advocacia Geral da União (AGU), por meio de uma iniciativa inédita, que conseguiu uma economia de 3,7 milhões em uma única licitação para contratação conjunta de serviços de telefonia móvel para 24 órgãos federais (BRASIL, 2013). Cader (2014) enumera que as vantagens dessa modalidade de aquisição são: possibilidade de realizar um planejamento mais adequado e a longo prazo das compras, criação de minuta de editais padrões, contribuindo para disseminar critérios de sustentabilidade e melhoria nas especificações e padronização dos bens e serviços, menos burocracia e avaliação conjunta do ciclo de vida dos produtos.

por biocombustível; aquisição de madeira e outros produtos certificados, papel reciclado e produtos biodegradáveis; impedimento para a participação de fornecedores que estejam sob pena de interdição de direitos previstos na Lei no 9.605/1998 (Lei de Crimes Ambientais).

\section{Contratação de serviços de limpeza e conservação, nos termos do Decreto nํ 5.940/2006}

O Decreto no 5.940/2006 instituiu a exigência da separação dos resíduos recicláveis descartados pelos órgãos públicos e impõe a sua destinação às associações e cooperativas formalizadas de catadores de materiais recicláveis. Essa iniciativa tem como objetivo fortalecer as organizações de catadores de materiais recicláveis, promovendo a inclusão socioeconômica da categoria. Assim, cumprir esse dispositivo legal, além de contribuir para a dimensão ambiental, contribui para a dimensão social.

\section{Destinação adequada dos entulhos gerados em contratação de serviços de Engenharia}

A Lei no 12.305, de 2010 (Política Nacional de Resíduos Sólidos); a Resolução no 307, de 5 de julho de 2002, do Conselho Nacional de Meio Ambiente (CONAMA); e a Instrução Normativa da Secretaria de Logística e Tecnologia da Informação/Ministério do Planejamento, Orçamento e Gestão (SLTI/MPOG) no 1, de 19 de janeiro de
2010, delimitam o tipo de rejeito de construção civil e sua destinação mais adequada. Destaca-se que deve ser estipulado que a contratada não poderá dispor os resíduos em aterros de resíduos domiciliares, lixões, encostas, corpos d'água, lotes vagos e áreas protegidas por lei nem ainda em áreas não licenciadas. 


\section{Produtos certificados}

Outra ferramenta interessante é a exigência de produtos certificados pelo INMETRO e que atendam às normas da ABNT. Além disso, os órgãos podem também exigir selos ou certificados ambientais, bem como certificação de economicidade. Por exemplo, nas licitações para aquisição de eletrodomésticos, os quais embora fossem de alto consumo e, muitas vezes, de uso contínuo, tais como ar condicionados, aspiradores de pó, geladeira, freezer, ventiladores e TVs, não contemplaram a exigência de nota mínima no Selo Procel de Economia de Energia. Esse selo constitui uma ferramenta simples e de importância para que o consumidor escolha eletrodomésticos com mais eficiência energética, dando nota de $A$ (mais eficiente) até $G$ (menos eficiente), bem como indicando o consumo de energia em kwh/mês.
Exigir produtos com melhores notas geraria economia de energia e ajudaria na preservação do meio ambiente, de forma prática e segura.

Também é importante incluir a exigência de madeira certificada, pois, além de seguir as leis aplicáveis, considera aspectos ambientais, sociais e econômicos na atividade florestal. Ou seja, a exploração e a extração de produtos da floresta, nestes casos, a priori, não são predatórias, uma vez que são observadas normas de segurança ocupacional na industrialização e existe o menor impacto ambiental, pois se conserva os recursos naturais ali existentes. Além disso, o custo atual de móveis que utilizam esse tipo de madeira fica em torno de apenas $5 \%$ a mais do que os de material não certificado (WWF, 2017).

\section{Impedimento para a participação de fornecedores que estejam sob pena de interdição de direitos previstos na Lei no 9.605/1998 (Lei de Crimes Ambientais)}

De acordo com a Lei no 9.605/1998, quando uma pessoa jurídica é punida em decorrência de crime ambiental, com penas de interdição temporária de direito, essa empresa fica proibida de "contratar com o Poder
Público, de receber incentivos fiscais ou quaisquer outros benefícios, bem como de participar de licitações, pelo prazo de cinco anos, no caso de crimes dolosos, e de três anos, no de crimes culposos" (BRASIL, 1998).

\section{APRESENTAÇÃO E ANÁLISE DOS DADOS}

Procedimentos e critérios utilizados nas contratações do Instituto Federal de Educação, Ciência e Tecnologia do Ceará - Campus Iguatu

Após a análise dos principais documentos e referenciais teóricos acerca das contratações sustentáveis, passa-se a apresentar os resultados alcançados com a pesquisa a partir do cotejamento entre documentos, referencial teórico e os critérios adotados nas contratações públicas do IFCE - Campus Iguatu. Esses são fruto da análise documental realizada nos processos licitatórios identificados ao longo de 2015, onde buscou-se averiguar em que medida os critérios de sustentabilidade indicados pelos teóricos foram incorporados aos procedimentos.

No exercício de 2015, o IFCE - Campus Iguatu realizou 66 procedimentos de compras: 25 licitações (16 pregões eletrônicos e nove adesões a atas externas do Sistema de Registro de Preços-SRP), 33 dispensas e oito procedimentos de inexigibilidade. Dessas contrações, a maior parte (66\%) corresponde a material destinado a suprir as demandas com gênero alimentício para os alunos, material de escritório e demais produtos para o cotidiano da instituição, enquanto o restante (40\%) serviu para atender à demanda de serviços, como treinamentos.
No ano em análise, a instituição realizou apenas licitações na modalidade de pregão eletrônico e por meio de adesão a atas de registro de preço. O pregão foi instituído pela Lei $n$ o 10.520/2002 e consiste em uma espécie de leilão, às avessas, onde basicamente ganha a empresa que ofertar o menor (melhor) valor para a contratação. O pregão pode ser realizado de forma presencial ou por meio da plataforma web do governo federal, denominada de Comprasnet, por meio do Sistema Integrado de Administração de Serviços Gerais (SIASG). Os pregões eletrônicos podem ser realizados com ou sem adesão ao SRP (sistema responsável por gerir as compras compartilhadas das instituições federais). Podem ser adquiridos por meio de pregão, os bens e os serviços que possuem características simples e que possam ser objetivamente definidos no edital. As outras modalidades de contratações utilizadas pelo IFCE - Campus Iguatu foram as dispensas e as inexigibilidades de licitação. 


\section{Os critérios de sustentabilidade empregados nos processos licitatórios do Instituto Federal de Educação, Ciência e Tecnologia do Ceará - Campus Iguatu}

Essa verificação foi pautada em dimensões extraídas dos teóricos e dos documentos que apoiaram essa investigação, sendo elas: dimensão social, econômica, de liberdade de escolhas e oportunidades; dimensão ética e jurídico-política; dimensão cultural; dimensão econômica; e dimensão ambiental.

\section{Dimensão social, econômica, de liberdade de escolhas e oportunidades}

Nesse item, estão descritos os critérios adotados pelo IFCE - Campus Iguatu, bem como se estes atendem concomitantemente às dimensões social, econômica e de liberdade de escolhas e oportunidades.

\section{Benefícios para as microempresas e as empresas de pequeno porte}

Os incentivos adotados pelo IFCE - Campus Iguatu para as ME e as EPP foram:

- Licitação com participação exclusiva de ME/EPP: - IFCE - Campus Iguatu utilizou, em sete pregões, o critério de participação exclusiva das ME e das EPP, contudo pode-se observar que esse procedimento foi utilizado apenas nas licitações, quando também poderia ter sido aplicado nos processos de dispensa. Ou seja, das 40 (33 dispensas + sete pregões) contratações em que seria possível adotar esse critério, o Campus adotou apenas em sete;

- Margem de preferência para ME/EPP: esse critério foi utilizado em todas as contratações do campus, que não utilizaram o critério da participação exclusiva das ME e das EPP;
- Prazo diferenciado para a comprovação da regularidade fiscal e trabalhista das ME/EPP: utilizado em todos os certames do campus.

Ocorre que o IFCE - Campus Iguatu não adotou outros critérios que poderiam ser de grande relevância para que a instituição possa alcançar maior sustentabilidade, quais sejam: exigência de subcontratação de $M E /$ EPP; cota para participação exclusiva de ME/EPP; prioridade para produtos nacionais; tratamento diferenciado para agricultores, $\mathrm{MEI}$, produtores rurais pessoa física e sociedades cooperativas de consumo; margem de preferência para empresas que cumprem o sistema de reserva de vagas para pessoas com deficiência. Salienta-se que esse último critério legal entrou em vigor apenas em 2016, ou seja, posteriormente aos processos de compras analisados na pesquisa documental, cujo período correspondia ao exercício de 2015.

\section{Aquisição de produtos da agricultura familiar para alimentação escolar}

A legislação em vigor exige que no mínimo $30 \%$ do valor repassado a estados, municípios e Distrito Federal para o PNAE devem ser utilizados na compra de gêneros alimentícios oriundos da agricultura familiar (BRA-

\section{Dimensão ética e jurídico-política}

\section{Divulgação das contratações}

Todas as contratações do IFCE - Campus Iguatu, exceto as dispensas de licitação, são publicadas no site que divulga as contratações do governo federal (Comprasnet) e no Diário Oficial da União. As licitações de valor a partir de R\$ 650 mil também são publicadas em um jornal de grande circulação (Diário do Nordeste). Além disso, as licitações realizadas na modalidade de pregão eletrônico
SIL, 2009). O IFCE - Campus Iguatu é uma autarquia federal, logo não possui a obrigação legal de atender a esse critério, contudo a instituição poderia também adotar esse importante critério de sustentabilidade. também são divulgadas no site institucional do IFCE Campus Iguatu. Destaca-se ainda que todos os contratos (independentemente da modalidade da contratação) são publicados no Diário Oficial da União.

Pode-se perceber que existe ampla divulgação e transparência quanto aos pregões e às licitações 
de grande valor, entretanto as dispensas e as licitações abaixo de $\mathrm{R} \$ 650$ mil (que são maioria na instituição), embora possuam a divulgação legalmente exigida (dimensão ética e jurídico-política), talvez não sejam capazes de alcançar parcela significativa da população, representada, por exemplo, por pequenos agricultores e comerciantes locais que não têm como hábito acessar o site de com- pras governamentais ou o Diário Oficial da União em busca de contratações públicas. Se tais compras fossem divulgadas em rádios comunitárias da cidade e no jornal local, haveria a possibilidade de inserir esses e outros grupos menos favorecidos nos certames, o que alcançaria a sustentabilidade na esfera social, a distribuição territorial e a liberdade de escolhas e oportunidades.

\section{Comissão para apuração de condutas das empresas licitantes}

A instituição possui uma importante ferramenta para agilizar a apuração de possíveis ilegalidades nas condutas das empresas participantes dos certames. Trata-se de uma comissão, nomeada por meio de portaria expedida pelo diretor-geral, a qual possui caráter de órgão técnico colegiado de assessoramento e assistência direta ao ordenador de despesa, responsável pelo cumprimento do que preconiza a Lei Federal no 8.666/1993 e demais dispositivos legais relativos ao tema licitações e contratos administrativos. Compete ainda a citada Comissão (IFCE, 2016) a:

\section{Análise jurídica do certame pela Procuradoria Federal}

Outra ação adotada pela instituição para garantir o cumprimento da legislação é o encaminhamento de todas as contratações, exceto das dispensas de licitação previstas no art. 24, I e II, da Lei no 8.666/93, para Procuradoria Federal para análise jurídica dos atos internos preparatórios, regularidade da escolha da mo-

\section{Consultas cadastrais e procedimentos básicos}

A instituição realiza várias consultas cadastrais prévias e procedimentos no decorrer do certame (Quadro 1). Caso ocorra alguma pendência em uma dessas consultas, a empresa não poderá participar do processo de contratação. São considerados exemplos a consulta ao Sistema de Cadastramento Unificado de Fornecedores (SICAF) (níveis I, II, III e IV); a qualificação técnica; atestados de capacidade técnica; a qualificação econômica; e outros.

Com base na análise documental realizada, percebe-se que todas as consultas e os procedimentos mencionados atendem a dimensão ética e jurídica da sustentabilidade. A declaração fornecida pelos participantes de que não empregam menores de 18 anos em trabalho
- I: Proposição de instauração de processo com vista à apuração de infrações cometidas no curso da licitação e do contrato, para promoção da responsabilidade administrativa e aplicação da sanção cabível;

- II: Execução de outras atividades, nos termos da legislação pertinente.

Essa ferramenta pode ser replicada em outros órgãos, a fim de garantir mais eficiência e efetividade quando for necessário investigar e aplicar sanções nas empresas que praticam condutas que ferem a ética e a legalidade dentro das contratações públicas.

dalidade licitatória etc. Tal atitude possibilita maior segurança para o gestor, evitando possíveis erros, ilegalidades ou desvios de condutas no decorrer do certame, bem como cumpre a exigência de parecer jurídico contido no art. 38, VI, da Lei no 8.666/93.

noturno, perigoso ou insalubre, e que não têm trabalhadores menores de 16 anos, salvo na condição de aprendiz, a partir de 14 anos, bem como as Certidões Negativas perante o INSS, o FGTS e a Justiça do Trabalho, tem como finalidade ser instrumento concretizador de direitos fundamentais dos empregados das empresas fornecedoras, por ser um meio coercitivo indireto de execução das verbas trabalhistas. Já a Certidão Negativa de Falência e Balanço Patrimonial segue os aspectos da sustentabilidade econômica, a fim de verificar se o fornecedor possui qualificação econômico-financeira suficiente para cumprir as exigências contratuais.

A Lei no 8.666/93, em seu artigo 29, IV, exige a apresentação da Certidão Negativa de Débitos Trabalhis- 
tas, porém seria mais completo e eficaz se o governo criasse um sistema de consulta para verificar também se a empresa já foi condenada pela Justiça do Trabalho por dumping social, pois pode ocorrer de uma empresa não ter débitos na Justiça do Trabalho quando da solicitação das negativas, mas possuir a citada condenação. Nesse caso, seu nome não apareceria negativado na Certidão de Débitos Trabalhistas. O IFCE - Campus Iguatu também poderia exigir declaração de que a empresa não mantém em seus quadros trabalhadores em condições análogas às de um escravizado, ou consultar se a empresa está no banco de dados do Ministério do Trabalho como praticante de tal conduta.

A instituição, por meio de seus editais analisados neste trabalho, não admite ainda a participação de fornecedores:
- Em processo de falência ou recuperação judicial, sob concurso de credores, em dissolução ou liquidação. Esse critério é adotado em razão do maior risco de insolvência ou de quebra da empresa, fazendo com que ela não consiga realizar a venda ou a prestação do serviço contratado, colocando em risco o erário público;

- Que estejam suspensos de licitar e impedidos de contratar com o IFCE ou com a administração pública;

- Que sejam reunidos em consórcio e sejam coligados ou subsidiários entre si. Tal medida se torna necessária, pois a participação na mesma licitação de empresas que possuam sócios ou capital em comum, prejudica o princípio da competitividade do certame;

\section{Quadro 1 - Critérios de sustentabilidade adotados pelo Instituto Federal de Educação, Ciência e Tecnologia do Ceará - Campus Iguatu.}

\begin{tabular}{|c|c|c|}
\hline & Critério adotado & Quantidade \\
\hline \multirow{3}{*}{$\begin{array}{l}\text { Dimensão de } \\
\text { igualdade de escolhas } \\
\text { e oportunidades e } \\
\text { dimensão social }\end{array}$} & Margem de preferência para ME e EPP. & 18 \\
\hline & $\begin{array}{l}\text { Prazo diferenciado para a comprovação da } \\
\text { regularidade fiscal e trabalhista de ME/EPP. }\end{array}$ & 66 \\
\hline & Licitação com participação exclusiva de ME/EPP. & 07 \\
\hline Dimensão social & $\begin{array}{l}\text { Declaração de que não emprega menores de } 18 \text { anos em trabalho } \\
\text { noturno, perigoso ou insalubre, bem como não tem trabalhadores } \\
\text { menores de } 16 \text { anos, salvo na condição de aprendiz, a partir de } 14 \text { anos } \\
\text { (conforme o art. 70, XXXIII, da Constituição Federal). }\end{array}$ & 25 \\
\hline \multirow{2}{*}{ Dimensão ambiental } & Materiais reciclados. & 1 \\
\hline & Madeira reflorestada. & 1 \\
\hline \multirow{6}{*}{ Dimensão econômica } & Contratações compartilhadas. & 15 \\
\hline & Consulta a certidões de improbidade administrativa. & 25 \\
\hline & Certidão negativa de falência e concordata. & 25 \\
\hline & $\begin{array}{l}\text { Impedimento para participação de empresas que sejam } \\
\text { reunidas em consórcio e sejam coligadas ou subsidiárias entre si. }\end{array}$ & 25 \\
\hline & Impedimento para empresas estrangeiras que não funcionam no Brasil. & 25 \\
\hline & $\begin{array}{l}\text { Cláusula para que a subcontratação seja admitida } \\
\text { somente com autorização do órgão contratante. }\end{array}$ & 3 \\
\hline \multirow{2}{*}{$\begin{array}{l}\text { Dimensão ética e } \\
\text { dimensão jurídico-política }\end{array}$} & Análise técnica e jurídica dos processos. & 33 \\
\hline & Publicidade e transparência. & 33 \\
\hline Dimensão jurídico-política & Consultas sobre regularidade fiscal e trabalhista. & 66 \\
\hline
\end{tabular}


- Estrangeiros que não funcionem no país, como forma de valorizar a mão de obra e a produção nacional, permitindo ainda que o montante auferido na licitação possa circular no Brasil;

- Fornecedor condenado por ato de improbidade administrativa. Seria possível ampliar essa consulta, incluindo na pesquisa o sócio majoritário da empresa, nos termos da Lei no 8.429/1992.

Além dessas restrições, é interessante que o IFCE Campus Iguatu e as demais instituições também possam prever em seus editais a não participação de empresas cujo quadro societário tenha servidor público do órgão realizador do certame, conforme dispõe o inciso III do artigo 9o da Lei no 8.112/1990. Não seria

\section{Dimensão cultural}

Neste subitem, foi realizada análise a partir da interseção dos dados coletados nos processos de contrata-

\section{Merenda escolar}

Nas contratações de gêneros alimentícios, para merenda escolar dos alunos, não foram encontrados itens que remetessem à rica cultura da região ou que privilegiassem produtos típicos e locais, por exemplo, rapadura e mandioca. Tais itens, além de seu rico teor

\section{Material utilizado para brindes em eventos}

$\mathrm{Na}$ contratação de materiais destinados a brindes para eventos dos servidores, percebe-se que poderiam ter sido escolhidos acessórios com aspectos culturais da região, por exemplo, peças de artesanato, tendo assim maior significado e simbolismo para a ocasião, seguindo parâmetros da dimensão cultural da sustentabilidade. Além dis-

\section{Obras e serviços de engenharia}

No exercício de 2015, o IFCE - Campus Iguatu não realizou contratações de serviços de engenharia, impos- difícil verificar essa informação, pois ela pode ser obtida no SICAF. Outra situação possível de inserir no edital seria restringir a participação de fornecedores que estejam sob pena de interdição de direitos previstos na Lei no 9.605/1998 (Lei de Crimes Ambientais).

Foi observada, ainda, em três editais de licitação da instituição, a imposição do fornecedor de utilizar o regime de subcontratação somente com autorização do órgão contratante. Esse critério de grande importância poderia ser utilizado nos demais editais, pois para que ocorra a subcontratação deve estar demonstrado o interesse público, bem como ser permitido apenas em casos muito específicos e respeitando um percentual de $30 \%$ do objeto licitado, não devendo estar ligado diretamente ao elemento fundamental do item. Em regra, a subcontratação deve ser evitada, para que o fornecedor não funcione como mero intermediário no negócio.

ções do IFCE - Campus Iguatu, sob a perspectiva da dimensão cultural.

nutricional, contribuiriam na valorização das tradições populares, sem esquecer dos demais benefícios relacionados às questões de ordem ambiental, pois a compra local também impede grandes deslocamentos de veículos para o transporte de produtos.

so, possivelmente, tais itens seriam adquiridos por meio de pequenos empreendedores (critério social e de divisão territorial), bem como, provavelmente, haveria economia, pois tais itens costumam ser menos onerosos (cada item adquirido na licitação custou $\mathrm{R} \$ 22$ ), atendendo, portanto, também a critérios econômicos de sustentabilidade.

sibilitando a análise mais aprofundada de critérios de sustentabilidade desse segmento.

\section{Dimensão econômica}

Do ponto de vista da dimensão econômica da sustentabilidade, o IFCE - Campus Iguatu adotou as medidas descritas a seguir. 


\section{Cláusulas contratuais}

Para evitar aumentos de valores e imprevistos no decorrer de um contrato, o IFCE - Campus Iguatu inseriu em seus editais uma cláusula especificando que, nos preços cotados, devem estar inclusas todas as despesas, de qualquer natureza, como mão de obra, impostos, frete, seguro, custos diretos e indiretos, tributos incidentes, todas as taxas, equipamentos, serviços, encargos sociais, trabalhistas; seguros, lucro e outras necessárias ao cumprimento integral do objeto do certame. Além disso, encontra-se

\section{Pesquisa de preço}

A instituição realiza as pesquisas de preço por meio do site do governo federal Comprasnet, por atas de registro de preço disponíveis/vigentes que possuíssem os itens pretendidos com melhores condições e preços. Além disso, pesquisa em um sistema privado, adquirido em 2015, que realiza cotações rápidas para verificar se os valores das atas estão compatíveis com os preços

\section{Contratações compartilhadas}

O IFCE - Campus Iguatu aderiu a nove processos licitatórios realizados por outras instituições, na modalidade de contratações compartilhadas, otimizando seus procedimentos e gerando economia para a administração pública. Além disso, o campus fez seis pregões originários no SRP, para que outras instituições pudessem participar do certame, contudo cabe destacar que a instituição poderia ter utilizado maior quantidade de contratações pelo SRP, pois foi possível verificar casos de dispensas de licitação que possuíam objeto semelhante. Tal fato pode caracterizar uma possível falha no planejamento, pois as três dispensas poderiam ser feitas em outra modalidade de processo licitatório, que possibilitasse maior publicidade e número de concorrente, gerando mais economia e eficiência no procedimento. Nesse caso, também seria mais adequado unir os dois certames fazendo a compra em uma única modalidade, em forma de pregão eletrônico, pois o valor total ultrapassaria o limite legal da dispensa de licitação. vedada qualquer indexação de preços por índices gerais, setoriais ou que reflitam a variação dos custos.

Em algumas licitações também foi possível observar a exigência de garantia de 12 meses para os produtos adquiridos e a obrigação de o licitante ganhador apresentar uma amostra ou fôlder do produto ofertado, para evitar da instituição comprar produtos de qualidade inferior ao pretendido.

praticados no mercado. Embora a forma adotada seja uma forma ágil de verificar os valores, poderia ser feita também uma pesquisa local, para ver se os preços praticados pelo mercado regional atenderiam à demanda por preço semelhante ao demonstrado no sistema de cotação, a fim de fomentar a participação do comércio local nos certames licitatórios.

Uma das recomendações possíveis seria no sentido de a instituição efetuar estimativa do consumo anual, mediante levantamento dos quantitativos adquiridos para um mesmo bem ou bens de uma mesma linha de fornecimento nos últimos 12 meses (dimensão econômica, dimensão social, dimensão ética-jurídica). Saliente-se que o art. 24, II, da Lei no 8.666/1993, dispõe que a administração pública não pode realizar mais de uma dispensa com o mesmo objeto, ou seja, partes de uma mesma compra ou serviço. Essa situação exige a realização de uma licitação de maior vulto que possa ser realizada de uma só vez. Além disso, poderia ter utilizado o Sistema de Cotação Eletrônica de Preços nas dispensas de licitação, em pelo menos 11 das 33 realizadas pela instituição em 2015. Cabe destacar que é recomendada a sua utilização para mais transparência dos processos de aquisição de bens de pequeno valor. Ressalta-se ainda que tal procedimento possibilita a redução de custos, em função do aumento da competitividade, bem como racionaliza os procedimentos administrativos, assegurando maior agilidade à contratação.

\section{Dimensão ambiental}

Analisando as contratações do IFCE - Campus Iguatu, sob a óptica da dimensão ambiental, foi possível realizar as análises descritas a seguir. 


\section{Aquisição de animais}

Nas contratações para a aquisição de aves, a instituição estipula uma cláusula exigindo que os animais estejam vacinados e que o fornecedor seja registrado no Ministério de Agricultura, Pecuária e Abastecimento, devendo ainda estar de acordo com as normas de protocolo de

\section{Material escolar}

Na contratação de kits de material escolar (farda, caderno, bolsa, borracha, canetas, lápis e estojo), a instituição licitou lápis revestido em madeira reflorestada e caderno em papel reciclado.

\section{Selos e certificados}

Outra ferramenta utilizada pela instituição é a exigência de produtos certificados pelo INMETRO e que atendam às normas da $A B N T$, contudo não há exigência de selos ou certificados ambientais, nem certifi-

\section{Material reciclado e biodegradável}

A aquisição de itens confeccionados em material reciclado não é regra para a instituição. As licitações para aquisição de resmas de papel A4, pastas, caixa-arquivos e demais materiais de expediente não contemplavam material reciclado. Destaca-se que o papel é, em geral, um dos insumos mais usados pelos órgãos públicos, em razão da necessidade de documentar todos os atos governamentais. Além disso, não há licitações de bem-estar para aves, conforme a União Brasileira de Avicultura. Essa cláusula tem grande importância, pois padrões de criação que seguem normas humanitárias permitem que os animais vivam de maneira mais saudável e ativa, além de ser menos danoso ao meio ambiente.

Considerando que todos os alunos da instituição são atendidos por tais kits, pode-se observar significativa diminuição nos impactos ambientais gerados pela instituição.

cação de economicidade. Quanto à licitação para a aquisição de mobiliário do campus, não há previsão editalícia de que a madeira utilizada na fabricação dos móveis seja certificada.

produtos biodegradáveis. Quanto aos produtos biodegradáveis, a instituição não os adquiriu em suas contratações do exercício analisado, entretanto tais aquisições são importantes, pois os produtos biodegradáveis são decompostos por microrganismos vivos, de forma que perdem suas propriedades químicas durante esse procedimento, contribuindo para o não acúmulo de lixo no planeta e agredindo menos o meio ambiente.

\section{Contratação de serviços de limpeza e conservação, nos termos do Decreto no 5.940/2006}

Inexiste na instituição contratação de serviços de limpeza e contratação nos termos do Decreto no 5.940/2006. O citado decreto institui a separação dos resíduos recicláveis descartados pelos órgãos públicos e impõe a sua destinação às associações e cooperativas formalizadas de catadores de materiais recicláveis, porém na cidade de Iguatu, a entidade de catadores é informal. Assim, os resíduos sólidos da instituição são em parte separados, por meio de lixeiras adaptadas; contudo, todo o lixo é misturado no momento da coleta. A cidade não possui coleta seletiva de lixo e o serviço de coleta existente não vai até o campus, em razão da distância deste até o centro da cidade. A instituição transporta seus resíduos sólidos até o lixão da cidade. Uma vez que é o próprio campus quem realiza o transporte dos resíduos, este poderia procurar formas de manter os resíduos separados, para posterior destinação na associação de catadores, que fica ao lado do lixão. Contudo, seria necessário, para tanto, fazer adaptações no caminhão do campus.

\section{Destinação adequada dos entulhos gerados em contratação de serviços de engenharia}

Conforme já informado, no exercício de 2015, o IFCE - Campus Iguatu não realizou contratações de serviços de engenharia, contudo deve-se des- tacar, aqui, que é interessante que seja inserido no edital e no contrato a obrigação da contratada de cumprir as diretrizes, os critérios e os procedi- 
mentos para a gestão dos resíduos da construção civil estabelecidos na Lei no 12.305, de 2010 (Política Nacional de Resíduos Sólidos); na Resolução no 307, de 05 de julho de 2002, do CONAMA; e na Instrução Normativa SLTI/MPOG no 1, de 19 de janeiro de 2010.

\section{RESULTADOS}

A aquisição sustentável baseia-se nos princípios e nas boas práticas de aquisição "tradicional" e considera fatores adicionais para maximizar benefícios sociais, ambientais, econômicos, entre outros, dentro da organização de compras, sua cadeia de suprimentos e sociedade como um todo. Com base nessa ideia, pode-se observar, a seguir, o resultado desta pesquisa acadêmica.

A análise da existência de critérios de sustentabilidade e sua forma de inserção nos processos de compras realizados pelo IFCE - Campus Iguatu, conduziu aos resultados que foram organizados no Quadro 1.

Os critérios mencionados anteriormente são os principais quando o assunto é sustentabilidade nas contratações do governo. Embora tais preceitos possuam previsão normativa, poucos possuem aplicação prática. Conforme dados fornecidos pelo painel de compras do governo federal (BRASIL, 2017), o quantitativo de aquisições com critérios de sustentabilidade no país possui um percentual ainda muito pouco expressivo e com crescimento anual ínfimo. Observam-se na Tabela 1 dados sobre alguns dos principais aspectos das contratações públicas sustentáveis no país.
Na Tabela 2, podem-se observar os mesmos parâmetros de sustentabilidade, porém nas contratações do IFCE - Campus Iguatu, no exercício de 2015. Cabe destacar que os maiores percentuais são aqueles que são regulamentados por legislação própria, a qual especifica de forma detalhada como deve ser implantado o critério de sustentabilidade. Esse é o caso da margem de preferência e da participação das ME/EPP, demonstrando, portanto, que caso os outros critérios possuíssem regulamentação em lei específica, poderiam ter maior adesão pelas instituições públicas.

Dessa forma, com esse comparativo fica evidente que o IFCE - Campus Iguatu, no ano analisado, possui percentuais acima da média nacional em relação à adoção de critérios de sustentabilidade. Cabe destacar que, de acordo com a realidade da instituição, ainda existem muitos outros critérios que podem ser atendidos, conforme exemplos citados no Quadro 2. Ressalta-se ainda que não foram encontrados critérios de sustentabilidade na dimensão cultural e na dimensão de distribuição territorial equilibrada nas contratações do IFCE Campus Iguatu.

Tabela 1 - Percentuais de critérios de sustentabilidade nas contratações públicas brasileiras.

\begin{tabular}{|l|c|c|c|c} 
Ano & $\begin{array}{c}\text { Compras com itens/ } \\
\text { produtos sustentáveis }\end{array}$ & $\begin{array}{c}\text { Compras com margem } \\
\text { de preferência }\end{array}$ & $\begin{array}{c}\text { Compras com } \\
\text { participação de ME/EPP }\end{array}$ & $\begin{array}{c}\text { Valor de compras } \\
\text { homologadas para ME/EPP }\end{array}$ \\
\hline 2015 & $0,85 \%$ & $1,13 \%$ & $51,20 \%$ & $15,29 \%$
\end{tabular}

ME: microempresa; EPP: empresa de pequeno porte.

Fonte: adaptado do painel de compras do Governo Federal (BRASIL, 2017).

Tabela 2 - Percentuais de critérios de sustentabilidade nas contratações públicas do Instituto Federal de Educação, Ciência e Tecnologia do Ceará - Campus Iguatu.

\begin{tabular}{|l|c|c|c|c} 
Ano & $\begin{array}{c}\text { Compras com itens/ } \\
\text { produtos sustentáveis }\end{array}$ & $\begin{array}{c}\text { Compras com margem } \\
\text { de preferência }\end{array}$ & $\begin{array}{c}\text { Compras com } \\
\text { participação de ME/EPP }\end{array}$ & $\begin{array}{c}\text { Valor de compras } \\
\text { homologadas para ME/EPP }\end{array}$ \\
\hline 2015 & 3,03 & $27,27 \%$ & $55,17 \%$ & $84,46 \%$ \\
\hline
\end{tabular}

ME: microempresa; EPP: empresa de pequeno porte.

Fonte: adaptado do painel de compras do Governo Federal (BRASIL, 2017). 
Quadro 2 - Critérios de sustentabilidade que podem ser adotados pelo Instituto Federal de Educação, Ciência e Tecnologia do Ceará - Campus Iguatu.

Dimensão

\section{tuto Federal de Educação, Ciência}

Dimensão social

e econômica

\section{Critério sugerido}

Margem de preferência para produtos nacionais.

Exigência de subcontratação de ME/EPP.

Cota para participação exclusiva de ME/EPP.

Dimensão social e dimensão da igualdade de escolhas e oportunidades

Tratamento diferenciado para agricultores, MEI e sociedades cooperativas de consumo.

Margem de preferência para empresas que cumprem o sistema de reserva de vagas para pessoas com deficiência ou para reabilitado da Previdência Social e que atendam às regras de acessibilidade previstas na legislação (este critério entrou em vigor apenas em 2016, período posterior ao material utilizado na análise documental).

Aquisição de produtos da agricultura familiar para alimentação escolar.

\section{Selo Procel.}

Selos e certificações ambientais.

Impedimento para a participação de fornecedores que estejam sob pena de interdição de direitos previstos na Lei n 9.605/1998 (Lei de Crimes Ambientais).

Produtos biodegradáveis.

Dimensão ambiental

Biocombustíveis.

\section{Madeira certificada.}

Destinação adequada aos entulhos gerados em contratação de serviços de Engenharia (não houve obras de Engenharia no período analisado).

Contratação de serviços de limpeza e conservação, nos termos do Decreto no 5.940/2006.

Aquisição de papel reciclado.

Dimensão ética

e dimensão

jurídico-política

Dimensão cultural
Impedimento para a não participação de empresas cujo quadro societário tenha servidor público do órgão realizador do certame, conforme dispõe o inciso III do artigo 9o da Lei $\mathrm{n}$ - 8.112/90.

Itens da cultura popular inseridos na merenda escolar.

Obras de Engenharia respeitando as características da arquitetura local (não houve obras de Engenharia no período analisado).

Serviços de contratação voltados para a urbanização com a plantação de mudas nativas.

ME: microempresa; EPP: empresa de pequeno porte; MEI: microempreendedor individual. 


\section{CONSIDERAÇÕES FINAIS}

A contratação pública sustentável é um processo em que os órgãos públicos conseguem satisfazer às suas necessidades de bens, serviços e obras, ao mesmo tempo que geram desenvolvimento não só para a organização, mas também para toda a sociedade. A análise da existência de critérios de sustentabilidade e sua forma de inserção nos processos de compras realizados pelo IFCE - Campus Iguatu conduziu às conclusões a seguir.

A instituição utiliza critérios de sustentabilidade acima da média nacional, embora a quantia adotada ainda não seja o percentual necessário. Contudo, deve-se observar que os maiores percentuais de critérios de sustentabilidade encontrados são aqueles regulamentados por legislação própria, a qual especifica de forma detalhada como deve ser implantado o critério. Esse é o caso da margem de preferência e do critério de participação exclusiva das ME/EPP. Nas outras instituições públicas federais brasileiras, a situação repete-se de forma muito semelhante, embora com percentuais ainda menores, demonstrando, portanto, que, se os demais critérios possuíssem regulamentação em lei específica, talvez houvesse mais adesão por parte das instituições públicas.

O maior desafio do IFCE - Campus Iguatu e das demais instituições públicas não é apenas comprar sustentavelmente, vai muito além disso: é necessária a adoção de ações que fomentem uma mudança cultural e de comportamento visando a um consumo consciente e sustentável. Para atingir esse objetivo, a inserção de critérios de sustentabilidade nas contratações públicas tem potencial como agente de transformação de tendências para um padrão de produção e consumo mais equilibrado, que possa apresentar à sociedade um novo paradigma de mercado.

\section{REFERÊNCIAS}

BIAGE, V. S. M.; CALADO, L. R. Análise dos Resultados das Contratações Públicas Sustentáveis. Revista Eletrônica de Administração, Porto Alegre, v. 21, n. 3, p.601-621, set./dez.2015. http://dx.doi.org/10.1590/1413-2311.0612014.54781

BRASIL. Compras Compartilhadas Sustentáveis: Critérios Ambientais com Ganhos Econômicos. Brasil: Governo Federal, 2017. Disponível em: <http://www.orcamentofederal.gov.br/projeto-esplanada-sustentavel/pasta-para-arquivardados-do-pes/Apresentacao_Compras_Compartilhadas_Sustentaveis.pdf>. Acesso em: 20 mar. 2017.

. Constituição da República Federativa do Brasil. Brasil, 1988. Disponível em: <http://www.planalto.gov.br/ ccivil_03/Constituicao/ConstituicaoCompilado.htm>. Acesso em: 5 set. 2017.

. Decreto no 5.940, de 25 de outubro de 2006. Brasil, 2006. Disponível em <http://www.planalto.gov.br/ ccivil_03/_ato2004-2006/2006/decreto/d5940.htm> Acesso em: mar. 2018.

. Decreto no 7.746, de 5 de junho de 2012. Brasil, 2012. Disponível em: <http://www.planalto.gov.br/ccivil_03/_ Ato2011-2014/2012/Decreto/D7746.htm>. Acesso em: 23 mar. 2017.

. Decreto no 8.538, de 6 de outubro de 2015. Brasil: Governo Federal, 2015a. Disponível em: <http://www. planalto.gov.br/ccivil_03/_ato2015-2018/2015/decreto/d8538.htm>. Acesso em: 12 fev. 2017.

Instrução Normativa no 01, de 19 de janeiro de 2010. Secretaria de Logística e Tecnologia da Informação/ Ministério do Planejamento, Orçamento e Gestão (SLTI/MPOG), 2010a. Disponível em: <https://www.governodigital. gov.br/documentos-e-arquivos/legislacao/INSTRUCAO\%20NORMATIVA\%20N.\%2001\%20de\%202010\%20-\%20 Compras\%20Sustentav.pdf/view> Acesso em: abr. 2018.

. Lei Complementar no 123, de 14 de dezembro de 2006. Estatuto Nacional da Microempresa e da Empresa de Pequeno Porte. Brasil, 2006. Disponível em: <http://www.planalto.gov.br/ccivil_03/leis/LCP/Lcp123.htm>. Acesso em: 23 jun. 2017. 
. Lei no 8.112, de 11 de dezembro de 1990. Brasil, 1990. Disponível em <http://www.planalto.gov.br/ccivil_03/ leis/l8112cons.htm> Acesso em: abr. 2018.

. Lei no 8.429, de 2 de junho de 1992. Brasil, 1992. Disponível em; <http://www.planalto.gov.br/ccivil_03/leis/ |8429.htm>. Acesso em: abr. 2018.

. Lei no 8.666, de 21 de junho de 1993. Normas para licitações e contratos da administração pública. Brasil, 1993. Disponível em: <http://www.planalto.gov.br/ccivil_03/leis//8666cons.htm>. Acesso em: 13 maio 2017.

. Lei no 9.605, de 12 de fevereiro de 1998. Brasil, 1998. Disponível em: <http://www.planalto.gov.br/ccivil_03/ leis/19605.htm> Acesso em: mar. 2018.

. Lei no 11.947, de 16 de junho de 2009. Programa Nacional de Alimentação Escolar. Brasil, 2009. Disponível em: <http://www.planalto.gov.br/ccivil_03/_ato2007-2010/2009/lei/l11947.htm>. Acesso em: 23 maio 2017.

. Lei no 12.305, de 2 de agosto de 2010. Política Nacional de Resíduos Sólidos. Brasil, 2010b. Disponível em: <https://www.planalto.gov.br/ccivil_03/_ato2007-2010/2010/lei/l12305.htm>. Acesso em: abr. 2018.

. Licitação compartilhada diminui custos com serviços de telefonia, 2013. Brasil, 2013. Disponível em: <http://www.brasil.gov.br/economia-e-emprego/2013/11/licitacao-compartilhada-diminui-custos-com-servicos-detelefonią). Acesso em: mar. 2018.

. Micro e pequenas empresas movimentam $R \$ 10,78$ bi nas compras públicas de 2015. Brasil: Governo Federal, 2015b. Disponível em: <http://www.brasil.gov.br/economia-e-emprego/2015/10/micro-e-pequenas-empresasmovimentam-r-10-78-bi-nas-compras-publicas-de-2015>. Acesso em: 4 mar. 2017.

CADER, R. Compras compartilhadas sustentáveis: construindo um novo paradigma. In: CONGRESSO BRASILEIRO DE GESTÃO DO MINISTÉRIO PÚBLICO: GESTÃO POR RESULTADOS, 5., 2014 Revista..., n. 5, p. 75-84, 2014.

CADER DA SILVA, R.; BARKI, T. V. P. Compras Públicas Compartilhadas: a prática das licitações sustentáveis. Revista do Serviço Público, v. 63, n. 2, p. 157-169, abr./jun. 2012. https://doi.org/10.21874/rsp.v63i2.93

CONSELHO NACIONAL DO MEIO AMBIENTE (CONAMA). Resolução no 307, de 5 de julho de 2002. Disponível em: <http://www2.mma.gov.br/port/conama/legiabre.cfm?codlegi=307>. Acesso em: abr. 2018.

FREITAS, J. Políticas públicas, avaliação de impactos e o direito fundamental à boa administração. Sequência, Florianópolis, n. 70, p. 115-133, jun. 2015. http://dx.doi.org/10.5007/2177-7055.2015v36n70p115

. Sustentabilidade: direito ao futuro. 2. ed. Belo Horizonte: Fórum, 2012.

GARCIA, F. A.; RIBEIRO, L. C. Licitações Públicas Sustentáveis. Revista de Direito Administrativo, Rio de Janeiro, v. 260, p. 231-254, maio/ago. 2012. http://dx.doi.org/10.12660/rda.v260.2012.8836

GELDERMAN, C. J.; SEMEIJN, J.; VLUGGEN, R. Development of sustainability in public sector procurement. Public Money \& Management, v. 37, n. 6, p. 435-442, 2017. https://doi.org/10.1080/09540962.2017.1344027

INSTITUTO FEDERAL DO CEARÁ (IFCE). Boletim de serviço - abril de 2016. Ceará: IFCE, 2016. Disponível em: <http:// ifce.edu.br/instituto/documentos-institucionais/boletim-de-servicos-1/iguatu/2016/bs-abril-2016.pdf/view>. Acesso em: 10 maio 2017.

LAVOR, A. A. A. de; TURATTI, L. Contratações públicas sustentáveis no Brasil. Gestão e Sustentabilidade Ambiental, Florianópolis, v. 7, n. 2, p. 335-354, abr./jun. 2018. https://doi.org/10.19177/rgsa.v7e22018335-354

MEIRELLES, H. L.; AZEVEDO, E. A.; ALEIXO FILHO, D. B. Direito Administrativo Brasileiro. 37. ed. São Paulo: Malheiros, 2011. 
MOREIRA, A. F. B.; CANDAU, V. M. Educação escola e Cultura(s): construindo caminhos. Revista Brasileira de Educação, Rio de Janeiro, n. 23, p. 156-168, 2003. http://dx.doi.org/10.1590/S1413-24782003000200012

ORGANIZAÇÃO DAS NAÇÕES UNIDAS (ONU). Relatório da Comissão Brundland. Report of the World Commission on Environment and Development: Our Common Future. Genebra: ONU, 1987. Disponível em: <http://www.undocuments.net/wced-ocf.htm>. Acesso em: 29 jan. 2017.

ORGANIZAÇÃO DAS NAÇÕES UNIDAS PARA A EDUCAÇÃO, A CIÊNCIA E A CULTURA (UNESCO). O papel da cultura no desenvolvimento sustentável. UNESCO. Disponível em: <http://www.unesco.org/new/pt/brasilia/culture/culture-anddevelopment/culture-in-sustainable-development/>. Acesso em: 29 jan. 2017.

ROOS, R. Sustainable Public Procurement: Briefing Note. Discussion paper prepared by Rita Roos on behalf of the United Nations Procurement Capacity Development Centre and the United Nations Environment Programme, 2012. Disponível em: <http://www.unpcdc.org/media/390120/spp_brief_en_2012-02-06.pdf>. Acesso em jul. 2018. SACHS, I. Caminhos para o desenvolvimento sustentável. 3. ed. Rio de Janeiro: Garamond, 2002.

. Desenvolvimento: includente, sustentável, sustentado. 2. ed. Rio de Janeiro: Garamond, 2004.

SILVA, R. C.; BETIOL, L.; VILLAC, T.; NONATO, R. Sustainable public procurement: the Federal Public Institution's shared system. Revista de Gestão, v. 25, n. 1, p. 9-24, 2018.

TEIXEIRA, M. F. F. B. Desafios e oportunidades para a inserção do tripé da sustentabilidade nas contratações públicas: um estudo dos casos do governo federal brasileiro e do governo do estado de São Paulo. 2013. 187f. Dissertação (Mestrado) - Programa de Pós-graduação em Desenvolvimento Sustentável, Universidade de Brasília, Brasília, 2013.

VEIGA, J. E. Desenvolvimento sustentável: o desafio do século XXI. 3. ed. Rio de Janeiro. Garamond, 2008.

. O Prelúdio do Desenvolvimento Sustentável. In: MERCANDANTE, A.; DELFIM NETTO, A.; LESSA, C.; HADDAD, E.; VEIGA, J. E.; BARROS, J. R. M.; BAER, M.; PAULANI, L. M.; POCHMANN, M.; ABRAMOVAY, R. Economia Brasileira: Perspectivas do Desenvolvimento, São Paulo: USP. p. 243-266, 2005.

jul.-set. 2006.

Neodesenvolvimentismo: quinze anos de gestação. São Paulo em Perspectiva, São Paulo, v. 20, n. 3, p. 83-94,

WORLD WILDLIFE FUND (WWF). O que é certificação florestal? Disponível em: <http://www.wwf.org.br/natureza_ brasileira/questoes_ambientais/certificacao_florestal>. Acesso em: abr. 2018. 